\title{
A Medicolegal Examination of Drowning Deaths - A Retrospective Study
}

\author{
Dr. Gajanan H Nayak ${ }^{1}$, Dr. Mahalaxmi Karlawad ${ }^{2}$ \\ ${ }^{1}$ Professor and Head, Karnataka Institute of Medical Sciences, Hubballi \\ ${ }^{2}$ Postgraduate, Student, Dept. Forensic Medicine and Toxicology, Karnataka Institute of Medical Sciences, Hubballi
}

\begin{abstract}
India is a vast country having plenty of water bodies' i.e. Rivers, ponds, wells and an extensive sea coast. So drowning is one of the most common causes of death among all manners of death in this country. This was a 2 year retrospective autopsy study of deaths due to drowning cases analyzed and tabulated. Study performed in department of Forensic Medicine \& Toxicology at KIMS, Hubballi from January 2014 to December 2015. We studied total 23 cases in two years, the maximum drowning cases were of male sex 14(60.86\%), with commonest age group being 11-20 years - 06 cases(26.08\%). Most of the drowning cases were accidental in nature 13(56.52\%) and occurred commonly in lakes and rivers 15(62.51\%). The most significant postmortem findings noted on autopsy were bleaching of skin 19(82.60\%) and presence of water in stomach in 13 cases (56.52\%).
\end{abstract}

Keywords: Drowning, age group, postmortem findings

\section{Introduction}

India is a vast country having plenty of water bodies' i.e. Rivers, ponds, wells and an extensive seacoast. In such a conducive environment, it is but natural that death due to drowning is a frequent event, where medico legal expertise is called upon for investigations. A recent global burden of disease (GBD) study reveals global mortality from drowning to be $7 \%$ of all injury related deaths (WHO, 2010). The world Health Organization estimates the annual global incidence of death by drowning to be $400,000 .{ }^{[1]}$ According to data from the Global Burden of Disease, during 2000 around 449,000 individuals died of drowning worldwide, while drowning also cost 1.3 million years of lost life and disability. ${ }^{[2]}$

Accidental drowning occurs often in India, nearly 40, 000 Indians die annually from drowning. It occurs occasionally among swimmers due to their rashness in swimming, but it occurs mostly in non-swimmers who venture to go beyond their depth in the sea, rivers, canals and lakes. Many lives are lost during floods, which are so frequent. It also occurs among persons at bathing places while bathing in deep water. Females may fall accidentally into a well while drawing water from it. Children may also accidentally fall into ponds or lakes while playing near their banks. They may even fall accidentally into domestic vessels of water, such as water tanks, bathtubs and buckets. ${ }^{[3]}$ Accidental drowning in shallow water is very rare, except when the individual happens to be intoxicated, insane or epileptic. ${ }^{[4]}$ The autopsy diagnosis of death by drowning can be one of the most difficult problems in forensic pathology because in our Indian setup the time required to complete the inquest formalities and transport of the body to the mortuary is enough for decomposition to set in, which masks most of the postmortem findings required to estimate the cause of death. And most of the bodies recovered from water are in various stages of decomposition. ${ }^{[5]}$

One of the most classical definition of drowning as provided by Roll as 'death by drowning is the result of hampering of the respiration by obstruction of respiratory tract by a fluid medium (usually water)'. ${ }^{6]}$

\section{Material and Methods}

This was a 2 years retrospective autopsy study of deaths due to drowning cases analyzed and tabulated. Study was performed in department of Forensic Medicine \& Toxicology at KIMS, Hubballi from January 2014 to December 2015.

\section{Objectives of Study}

1) To study the manner of death and categories whether the form of drowning deaths were accidental, suicidal or homicidal in nature.

2) To confirm whether the drowning was antemortem in nature

3) To study the specific findings of drowning deaths in postmortem examination.

\section{Observations and Results}

The present study has been performed on 23 cases of drowning deaths which were brought to Karnataka Institute of Medical Sciences, Hubballi, for routine medico legal autopsy.

Table No. 1 showing sex-wise distribution, out of total of 23 cases that were studied, $14(60.86 \%)$ were males \& 09 $(39.13 \%)$ were females. Thus it is obvious that the majority of cases reported for postmortem examination were males.

Table No. 2 showing age wise distribution, out of 23 cases studied, the incidence of drowning was found in all age groups.

The maximum number of cases studied belonged to the age group of $11-20 \mathrm{yrs}$ and the minimum number of the cases was reported in age group of $71-90$ yrs. 


\section{International Journal of Science and Research (IJSR) \\ ISSN (Online): 2319-7064 \\ Index Copernicus Value (2015): 78.96 | Impact Factor (2015): 6.391}

Table No. 3 showing manner of death, Out of the total of 23 cases of drowning, it was found that 13 cases $(56.52 \%)$ were accidental, 10 cases $(43.47 \%)$ were suicidal. Significantly we did not find any case of homicidal drowning.

Table No. 4 showing the postmortem findings drowning cases. Significantly, we did not find any case of dry drowning.

Table No: 5 showing place of occurrences, lakes and rivers being the commonest sources, 15(65.21\%)cases, 03(13.04\%) cases in wells,04(17.39\%) cases in house tanks and 01 $(4.34 \%)$ case in swimming pool were observed.

Table 1: Sex Wise Distribution

\begin{tabular}{|c|c|c|}
\hline Male & Female & Total \\
\hline $14(60.86 \%)$ & $09(39.13 \%)$ & 23 \\
\hline
\end{tabular}

Table 2: Age Wise Distribution

\begin{tabular}{|c|c|}
\hline Age Group In Years & Total Cases \\
\hline $0-10$ & $02(08.69 \%)$ \\
\hline $11-20$ & $06(26.08 \%)$ \\
\hline $21-30$ & $03(13.04 \%)$ \\
\hline $31-40$ & $02(08.69 \%)$ \\
\hline $41-50$ & $03(13.04 \%)$ \\
\hline $51-60$ & $02(08.69 \%)$ \\
\hline $61-70$ & $03(13.04 \%)$ \\
\hline $71-80$ & $01(04.34 \%)$ \\
\hline $81-90$ & $01(04.34 \%)$ \\
\hline
\end{tabular}

Table 3: Manner of Death

\begin{tabular}{|c|c|c|c|}
\hline Suicidal & Accidental & Homicidal & Total \\
\hline $10(43.47 \%)$ & $13(56.52 \%)$ & 00 & 23 \\
\hline
\end{tabular}

Table 4: Postmortem Findings

\begin{tabular}{|c|c|c|}
\hline S1.No & Pm Findings & Total Cases \\
\hline 01 & Cyanosis & $05(21.73 \%)$ \\
\hline 02 & Froth from mouth and nostrils & $08(34.78 \%)$ \\
\hline 03 & Washer woman's hands and feet & $05(21.73 \%)$ \\
\hline 04 & Bleaching of skin & $19(82.60 \%)$ \\
\hline 05 & Internal petechial hemorrhages & $04(17.39 \%)$ \\
\hline 06 & $\begin{array}{c}\text { Presence of heavy, voluminous, edematous } \\
\text { and congested lungs with c/s showing } \\
\text { copious frothy fluid }\end{array}$ & $12(52.17 \%)$ \\
\hline 07 & Presence of water in stomach & $13(56.52 \%)$ \\
\hline 08 & Animal bites and Decomposition & $04(17.39 \%)$ \\
\hline
\end{tabular}

Table 5: Place of Occurrence

\begin{tabular}{|l|l|l|}
\hline 01 & Lakes/Rivers & $15(65.21 \%)$ \\
\hline 02 & WELLS & $03(13.04 \%)$ \\
\hline 03 & HOUSE TANKS & $04(17.39 \%)$ \\
\hline 04 & SWIMMING POOLS & $01(4.34 \%)$ \\
\hline
\end{tabular}

\section{Discussion}

Drowning is defined as the impairment of tissue oxygenation consequent to submersion in a fluid medium. ${ }^{[3]}$

According to Mason $\mathrm{JK}^{[7]}$, the precise number of drowning fatalities on a worldwide basis is uncertain but is probably around some 140, 000 people per year. The trend is increasing worldwide due to increase in water transport, and adventure water sports.
According to Modi ${ }^{[8]}$, Accidental drowning occurs often in India, nearly 40, 000 Indians die annually from drowning. It occurs occasionally among swimmers due to rashness in swimming, but it occurs mostly in non-swimmers who venture to go beyond their depth in sea, rivers, canals, and lakes etc.

$\operatorname{Modi}^{[8]}$ observed that in India drowning occupies the first position of all models of committing suicide. In his study of 231 cases of suicide, 90 were due to drowning. Indian females, even on the least provocation, commit suicide by jumping into a well or a tank in the neighborhood.

In our study of total 23 cases of drowning, 14(60.86\%)were males \&09(39.13\%)were females. In all age groups males predominated. Male dominance in drowning deaths were shown in many other studies by Kanchan $\mathrm{T}$ et al, Chowdhury B L et al, Byard R W et al, Davoudi-Kiakalayeh A et al .[9,10,11,12]ArdeshirSheikhazadi et al (2009) found in their study in Iran that male - female ratio was 6.5:1 among drowning deaths [13].The percentage of drowning deaths where the deceased was a male in various studies Sayed $\mathrm{ZAT}^{[14]}(75.68 \%)$, Chormunge et $\mathrm{al}^{[15]}(73.53 \%)$, Amandeep Singh et $\mathrm{al}^{[16]}(67.56 \%)$, Salachin et $\mathrm{al}^{[17]}(75.6 \%)$, Gross VA et $\mathrm{al}^{[18]}(90 \%)$, Momanchand et $\mathrm{al}^{[19]}(80.3 \%)$, and Srinivasa Reddy $\mathrm{P}^{[20]}$ (59.14\%).

In our study, we found most common incidence of drowning occurred in the age group of $11-20$ yrs i.e. 06 cases (26.08\%), followed by the age groups $21-30 \mathrm{yrs}, 41-50 \mathrm{yrs}$ and 61 to $70 \mathrm{yrs}$, with 03 cases each(13.04\%).In the age group of 0-10 yrs, 31-40 yrs and 51-60 yrsthere were 02 cases each $(08.69 \%)$ and the least common age group was $81-90$ yrs i.e. 1 case $(1.43 \%)$. Thus the maximum number of cases in our study belonged to the age group of $11-20$ yrs. and the minimum numbers of the cases were reported in age group of 81-90 yrs. Considering other references in same field, Prabir et al in their study in 2015 had maximum cases(13cases) of drowning between 11-20 years of age, ${ }^{[21]}$ Manjunath S (2010) in their study at Manipal found that the age group commonly involved in drowning was 11-20 years $^{[22]}$, Davoudi-Kiakalayeh A et al (2008) in their study in Iran also found that more than one third of the victims were less than 20 years of age ${ }^{[12]}$. Results of these studies corroborated with our findings.

In present study, it was also found that 13 cases $(56.52 \%)$ were accidental and 10 cases $(43.47 \%)$ were suicidal in nature. Similar observations were made in study done by Mukherjee AA et al,wherein 26 cases (37.14) were accidental and 19 cases $(27.14 \%)$ were suicidal and in 25 cases $(35.72 \%)$ police did not ascertain the manner of death [3]. The probable explanation to the above may be that as drowning deaths are mostly suicidal and accidental in nature, the age group 11- 50 yrs. are more vulnerable as this age is more prone to accidents in water during adventure sports, travels and swimming. The challenges and struggle for livelihood in adolescents, frustrations due to failure of high ambitions and in love affairs makes them more prone for suicide.

As far as the postmortem findings seen in drowning cases, out of the total of 23 cases, cyanosis was observed in 


\section{International Journal of Science and Research (IJSR) \\ ISSN (Online): 2319-7064}

Index Copernicus Value (2015): 78.96 | Impact Factor (2015): 6.391

$05(21.73 \%)$, oozing of whitish to pinkish froth, copious in amount from mouth and nostrils was found in 08(34.78\%) cases, bleached skin was observed in $19(82.60 \%)$ cases and washer woman's hands \& feet were observed in $05(21.73 \%)$ cases. Internal petechial hemorrhages over pleura, pericardium, under scalp, over the lungs and in the interlobar areas were found in $04(17.39 \%)$ cases. In $12(52.17 \%)$ cases we observed the presence of heavy, voluminous, oedematous and congested lungs, with weight of either lung above $500 \mathrm{gm}$ and with presence of copious amount of whitish, fine, leathery froth oozing out freely on cut section. Significantly, we did not find any case of dry drowning. The presence of water in stomach and first part of small intestine was observed in $13(56.52 \%)$ of cases. Animal bites and decomposition changes were noted in 04 cases $(17.39 \%)$

In our study, in 15 cases $(65.21 \%)$ drowning occured in lakes/rivers, followed by 04 cases $(17.39 \%)$ in house tanks, 03 cases $(13.04 \%)$ in wells and $01(04.34 \%)$ case in swimming pool. Similar observation were made in study done by Chidanand $\mathrm{C}$ et al, where the commonest place of submersion was lakes $(37.6 \%)$ followed by wells $(17.8 \%) .{ }^{[23]}$ Study done by Prabir et al, showed maximum cases drowned in ponds $21(35 \%)$, followed by rivers $17(23 \%)$ and lakes $13(22 \%){ }^{[21]}$

\section{Conclusion}

This study reveals that the maximum drowning cases were of male sex 14(60.86\%), with commonest affected age group being 11-20 years, i.e. 06 cases $(26.08 \%)$. Most of the drowning cases were accidental in nature 13(56.52\%) and occurred commonly in lakes and rivers 15 (62.51\%). The most significant findings noted on autopsy were bleaching of skin -19 cases $(82.60 \%)$ and presence of water in stomach 13 cases $(56.52 \%)$.

At the end it may be said that the study carried out is neither easy nor noncontroversial but it is likely to open the doors for carrying on constant reconsideration, Government legislation, community participation related to proper swimming lessons, aquatic safety measures and evaluation of the problem for its improvement and throw light on the present state.

Some preventive measures that can be implemented to avoid drowning such as unattended underground tanks should not be kept open. Proper engineering and meshing/closing of the construction tanks and drainages should be made compulsory. Fencing and meshing of the lakes with prominent warning signals may reduce the rate of accidental submersions. Introduction of resuscitation education and swimming lessons to the curriculum of the children can do better. Parents and or caregivers should be advised not to leave the children alone/unattended.

In our study the number of drowning cases that presented to Karnataka Institute of Medical Sciences, Hubballi are less because, rapid urbanization has resulted in loss of natural water reservoirs and most of the cases are taken to local primary health care centers for autopsy.

\section{Conflict of Interest}

Nil

\section{Source of Funding}

Self

\section{Consent}

Not taken as it was autopsy based retrospective study

\section{References}

[1] Brundtland GH. From WHO Reducing risks to health, promoting healthy life. JAMA 2002; 288(16):1974.

[2] Peden MM, Mc Gee K. The epidemiology of drowning world wide. Inj Control SafPromot 2003; 10(4):195-9.

[3] Mukherjee AA, DhawaneSG, Dhoble SV. Medicolegal study of drowning deaths: a forensic perspective. Journal of Research in Forensic Medicine and Toxicology; Vol 2, Issue 1, Jan-June 2016; Page 1-4.

[4] Mathiharan K, Patnaik AK. Modi's Medical Jurisprudence and Toxicology, $23^{\text {rd }}$ ed. New Delhi: Lexis Nexis 2006:610-11.

[5] Ranga Rao et.al, Sch. J.App.Med.Sci.,2014;2(4D):13971401.

[6] H.F.Roll, Leerboek der GerechtelijkeGeeneeskundevoor de scholen tot opleiding van Ind.Arsten, 'SGravenhage, Martinus Nijhoff, 1918.

[7] Mason JK, The pathology of trauma $2^{\text {nd }}$ ed. Edward Arnold 1993:204-26.

[8] Modi JP. Textbook of Medical Jurisprudence and Toxicology, $21^{\text {st }}$ ed. N.M.Tripathi Private Ltd 1996:188220.

[9] Dr.Tanuj Kanchan, Dr.Prateekrastogi, Dr.Manoj Kumar Mohanty, Profile of near drowning victims in coastal region of Karnataka, JIAFM,2007;29(4).

[10] Chaudhary B.L, Singh Deepak, MeelVeena, Tirpude B.H, Study of drowning cases in Kasturba Hospital Sevagram, Wardha, Journal of Forensic Medicine and Toxicology 2005:22(2):29-30.

[11]Roger W.Byard,M.D.GillianHouldsworth, Ross A.James and John D.Gilbert, Characteristic Featuresof Suicidal Drowning A 20year study, The American Journal of Forensic Medicine and Pathology 2001;22(2):134-138.

[12] Davoudi-Kiakalayeh A, Mohammadi R, Stark-Ekman D, Yousefzade-Chabok S, Behboudi F, Jamson B. Estimating drowning deaths in Northern Iran using capture-recapture method. Health Policy 2011:100(23):290-296.

[13] Ardeshir S, Mohammad H G, Epidemiology of Drowning in Isfahan Province, cener of Iran. J.Res Med Sci.2009, March-April;13(2):79-87.

[14] Sayed ZAT, Farhat HM, Hamid AP. Medicolegal investigation of violent asphyxial deaths-an autopsy based study. Journal of the Dow University of Health Sciences, Karachi 2012;6(3):86-90.

[15] Vijay C, Prashant B, Ajay S. Violent asphyxial deaths in rural area of Maharashtra. Indian Journal of Forensic Medicine and Pathology 2009;2(4):161-4. 


\section{International Journal of Science and Research (IJSR) \\ ISSN (Online): 2319-7064}

Index Copernicus Value (2015): 78.96 | Impact Factor (2015): 6.391

[16] Singh A, Goria RK. A study of demographic variables of violent asphyxial death. JPAFMAT 2003;3:22-5.

[17] Salachin S. An analysis of the medicolegal autopsies performed in adana, Turkey, in 1983- 1988. American Journal of Forensic Med and Pathology 1991;12(3):191 93.

[18] Gross VA, Weiss MG, Ring M, et al. Method of suicide: international suicide patterns derived from WHO mortality database. Available at: www.unece.org/trans/conventn/distsigns.pdf.

[19] Momamchand A. Violent asphyxial deaths in imphal. Journal of Forensic Medicine \& Toxicology 1998;15(1):60-4.

[20] Reddy SP, Kumar R, Rudramurthy. Asphyxial deaths at district hospital, Tumkur a retrospective study. J Indian Acad Forensic Med 2012;34(2):146-147.

[21] Prabir et al, Histopathological changes in lungs and spleen in cases of drowning with demographic variability, European Journal of Biomedical and Pharmaceutical Sciences, 2015 2(2):479-485.

[22] Palimar V, Manjunath S. drwoning deaths in Manipal. Int. J Med Toxicol Legal Med.2010 Apr-Jun; xii(4): ISSN:0972-0448.

[23] Chidanand C, Satish K.V. Study of incidence of middle ear hemorrhage in drowning. Journal of evidnce based Medicine an dHealth care: 2(6) Feb 09,2015;621-628. 